\title{
Article \\ Screening of Functional Compounds in Supercritical Carbon Dioxide Extracts from Perennial Herbaceous Crops
}

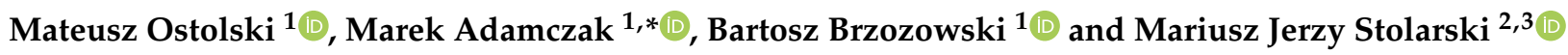 \\ 1 Department of Process Engineering Equipment and Food Biotechnology, Faculty of Food Science, \\ University of Warmia and Mazury in Olsztyn, Jan Heweliusz St. 1, 10-718 Olsztyn, Poland; \\ mateusz.ostolski@uwm.edu.pl (M.O.); bartosz.brzozowski@uwm.edu.pl (B.B.) \\ 2 Department of Genetics, Plant Breeding and Bioresource Engineering, Faculty of Agriculture and Forestry, \\ University of Warmia and Mazury in Olsztyn, Plac Łódzki 3, 10-724 Olsztyn, Poland; \\ mariusz.stolarski@uwm.edu.pl \\ 3 Centre for Bioeconomy and Renewable Energies, University of Warmia and Mazury in Olsztyn, Plac Łódzki 3, \\ 10-724 Olsztyn, Poland \\ * Correspondence: marek.adamczak@uwm.edu.pl
}

check for updates

Citation: Ostolski, M.; Adamczak, M.; Brzozowski, B.; Stolarski, M.J. Screening of Functional Compounds in Supercritical Carbon Dioxide Extracts from Perennial Herbaceous Crops. Agriculture 2021, 11, 488. https:// doi.org/10.3390/agriculture11060488

Academic Editor: Ângela Fernandes

Received: 22 April 2021

Accepted: 21 May 2021

Published: 25 May 2021

Publisher's Note: MDPI stays neutral with regard to jurisdictional claims in published maps and institutional affiliations.

Copyright: (c) 2021 by the authors. Licensee MDPI, Basel, Switzerland. This article is an open access article distributed under the terms and conditions of the Creative Commons Attribution (CC BY) license (https:// creativecommons.org/licenses/by/ $4.0 /)$.
Abstract: The bio-based economy concept requires using biomass not only for energy production but also for bioactive compound extraction, application or biotransformation. This study analyzed the possibility of obtaining bioactive compounds from biomass before its transformation into biofuel. This involved an analysis of the total content of polyphenols (TPC), flavonoids (TFC), and spectral analysis using Fourier transform infrared spectroscopy (QATR- FTIR) as well as analysis of the antioxidant activity of extracts from selected perennial herbaceous crops cultivated on marginal lands in Poland. The extracts were obtained by supercritical carbon dioxide extraction $\left(\mathrm{scCO}_{2}\right)$ or $\mathrm{scCO}_{2}$ with water as a cosolvent $\left(\mathrm{scCO}_{2} / \mathrm{H}_{2} \mathrm{O}\right)$ from biomass of the following plants: Helianthus salicifolius, Silphium perfoliatum, Helianthus tuberosus, Miscanthus $\times$ giganteus, Miscanthus sacchariflorus, Miscanthus sinensis and Spartina pectinata. The biomass was harvested twice during the growing period (June and October) and once after the end of the growing period (February). For most of the analyzed extracts obtained from biomass at the growing stage using $\mathrm{scCO}_{2}$ or $\mathrm{scCO}_{2} / \mathrm{H}_{2} \mathrm{O}$, a higher TPC was noted than for samples of semi-wood or straw biomass obtained after the end of the growing period. Higher contents of polyphenolic compounds were recorded in extracts obtained using $\mathrm{scCO}_{2} / \mathrm{H}_{2} \mathrm{O}$. A positive correlation between TPC and antioxidant activity was noted for the analyzed substrates. Flavonoid contents varied in the analyzed samples, and higher contents were generally obtained in $\mathrm{sCCO}_{2}$ extracts from biomass harvested at the beginning of the growing period. A high diversity of extract compositions was confirmed by spectral analysis. The presented data can be used at the initial stage of planning a biorefinery.

Keywords: polyphenols; supercritical $\mathrm{CO}_{2}$ extraction; perennial industrial crops; antioxidant activity; silvergrass; Jerusalem artichoke; willowleaf sunflower; cup plant; prairie cordgrass

\section{Introduction}

One of the most attractive renewable sources of energy is plant biomass, particularly perennial plants that are not used in food production [1-3]. However, as the data show, the profitability of producing energy from plant biomass is not always satisfactory. Therefore, consideration should be given to both its multidirectional use and solutions appropriate for sustainable technologies [4]. Perennial plants, including perennial herbaceous crops, offer a wide variety of environmental benefits when compared with annual species. Due to economic reasons resulting from the single-purpose use of perennial plants as solid biofuel, they are currently mainly cultivated on an experimental scale (excluding Miscanthus $\times$ giganteus). However, the possibility of multidirectional use of these species as substrates for biogas plants, second-generation biofuels or bioproducts (with regard to the content of specific compounds) has been increasingly more frequently indicated. 
The great diversity of polyphenolic compound structures determines their varied biological activity. Polyphenols are widespread compounds that are safe, cheap and effective for many applications. The contribution of polyphenols to the prevention of cardiovascular diseases, neoplasms, prostate diseases and osteoporosis has been confirmed, and their role in the prevention of diabetes mellitus and neurodegenerative diseases has been suggested [5-7]. Polyphenols can also be used in the food industry as natural antioxidants that delay food spoilage [8]. There has been great interest in the use of plant extracts or selected polyphenols in the synthesis of metal nanoparticles [9]. It is also possible that the poor stability, solubility and bioavailability of polyphenols could be solved by the application of encapsulation, e.g., synthetic polyphenol-loaded nanoparticles [10].

Antioxidants can be synthesized in vivo or taken as dietary antioxidants in the form of mainly phenols and polyphenols from plants, i.e., from the stems, roots, bark, leaves, fruits and seeds [11]. It is estimated that two-thirds of the world's plant species display medicinal importance, and almost all of these have excellent antioxidant potential. The antioxidant activity of polyphenols results from a direct reaction with ROS or the stimulation of natural processes that contribute to an improvement in the cellular resistance to oxidative stress [12].

These compounds reduce the virulence of microorganisms, inhibit biofilm formation [13], inhibit quorum sensing [14] and neutralize bacterial toxins [15].

There is no information on extracts obtained using supercritical carbon dioxide $\left(\mathrm{scCO}_{2}\right)$ from perennial industrial crops (PIC), particularly from herbaceous crops. These plants can be used for the production of food and pharmaceuticals and as renewable energy sources. However, no analyses are available on the effects of the growing phase on the efficiency of polyphenolic compound extraction using $\mathrm{scCO}_{2}$. The cultivation and application of new plants could influence and protect the natural environment [16]. For example, $H$. tuberosus exhibits varied pharmacological properties. It displays, inter alia, aperient, cholagogue, diuretic, spermatogenic, stomachic and tonic effects and has been used in folk medicine for the treatment of diabetes and rheumatism [17]. Moreover, extracts of H. tuberosus L. exhibit antibacterial, antifungal and antineoplastic activities. The leaves and tubers of Jerusalem artichoke are rich sources of phenolic and flavonoid compounds. The leaves contain much higher concentrations of those substances compared to the tubers [18]. Research on the biological activity of $S$. perfoliatum extracts has confirmed their antifungal as well as wound healing accelerating properties. Their antibacterial activity against Gram-positive (Enterococcus faecalis and Staphylococcus aureus) and Gram-negative (Escherichia coli and Pseudomonas aeruginosa) bacteria has also been noted [19], along with the positive effect of S. perfoliatum extracts on the stability of sunflower oil fatty acid composition [20].

The cultivation conditions and the harvesting period affect the chemical composition of plant biomass, including polyphenolic compounds [21]. The large number of components of plant extracts requires the selection of appropriate extraction techniques, which play a crucial role in the qualitative and quantitative characterization of the product. To the authors' knowledge, there are no studies on the general characteristics of bioactive polyphenolic compounds obtained by green extraction technique using $\mathrm{scCO}_{2}$ from $S$. pectinata and H. salicifolius, and there is limited information on polyphenols from other analyzed biomasses. The presented data can be used at the initial stage of planning a biorefinery. Lignocellulosic biomass was delignified during extraction using organic solvents and $\mathrm{scCO}_{2}$ at temperatures above $150{ }^{\circ} \mathrm{C}$. A higher degree of lignin removal was demonstrated in extractions using pure $\mathrm{scCO}_{2}$ than with $\mathrm{scCO}_{2}$ /water [22].

The current study aimed to screen the polyphenolic compound content and antioxidant activity in extracts obtained using supercritical carbon dioxide from the biomass of perennial herbaceous crops collected in three different phases of plant growth. Attenuated total reflection Fourier transform infrared (QATR-FTIR) spectral analyses of the selected extracts were performed to obtain data on the general characteristics of functional groups of bioactive compounds. 


\section{Materials and Methods}

\subsection{Chemicals}

The following chemical reagents were used in the experiments: dimethyl sulfoxide (DMSO, $\geq 99 \%$, Stanlab, Lublin, Poland), methanol ( $\geq 99 \%$, Stanlab), Folin-Ciocalteu reagent (Aktyn, Suchy Las, Poland), sodium carbonate ( $\geq 99 \%$, Stanlab), gallic acid ( $\geq 98 \%$, Sigma Aldrich, Poznan, Poland), 2,2-diphenyl-1-picrylhydrazyl, (DPPH, Sigma Aldrich), quercetin ( $\geq 95 \%$ Sigma Aldrich) and 6-hydroxy-2,5,7,8-tetramethylchromane-2-carboxylic acid (Trolox, $\geq 98 \%$, Sigma Aldrich).

\subsection{Harvesting of the Plant Material}

The biomass of the following species of herbaceous (semi-woody) crops was extracted: Helianthus salicifolius A. Dietr, Silphium perfoliatum L., Helianthus tuberosus L., Miscanthus $\times$ giganteus J.M. Greef \& M. Deuter, Miscanthus sacchariflorus (Maxim.) Hack, Miscanthus sinensis (Thunb.) Andersson and Spartina pectinata Bosc ex Link. Perennial crops were obtained from the experimental fields of the University of Warmia and Mazury in Olsztyn, located in north-eastern Poland. The details of the sample preparation and extraction were presented by Stolarski et al. [22] and recently by Malm et al. [23] and Ostolski et al. [24]. Entire plants were harvested three times in one year (2018) within one field experiment, where plants regrew following consecutive harvests. One-year-old plants that grew throughout the entire vegetation period of 2017 were harvested in the third decade of February 2018 (biomass C). The collected biomass was in the form of straw or semi-wood featuring a moisture content of approximately $20 \%$. In the third decade of June 2018 (biomass A), a three-month-old biomass in the form of young green shoots was collected from the previously (February 2018) harvested field. Finally, in the third decade of October 2018 (biomass B), crop regrowth in the form of young green shoots was gathered from the plots harvested in June 2018. The moisture content of the biomass obtained in June and October ranged from $60 \%$ to $70 \%$. Each biomass was dried in a convection dryer (Memmert, Schwabach, Germany) at $40{ }^{\circ} \mathrm{C}$ for 7 consecutive days to achieve a moisture content below $10 \%$, followed by grinding in a hammer mill using a $1 \mathrm{~mm}$ sieve.

\subsection{Extraction Conditions}

The experiments were carried out in a pilot plant extractor with two high-pressure extraction vessels, each with a capacity of approximately $40 \mathrm{dm}^{3}$ (NATEX, Ternitz, Austria). Biomass batches of $5 \mathrm{~kg}$ were prepared, and supercritical extraction was performed under the following conditions: $40{ }^{\circ} \mathrm{C}$ and $33 \mathrm{MPa}$ using $\mathrm{scCO}_{2}$ or $\mathrm{scCO}_{2}$ and $40 \%(w / w$ based on biomass weight) water $\left(\mathrm{scCO}_{2} / \mathrm{H}_{2} \mathrm{O}\right)[23,24]$. The water from the collected extracts was evaporated using a vacuum evaporator at $50{ }^{\circ} \mathrm{C}$.

To prepare the working solution, $50 \mathrm{mg}$ of the extracts was mixed in $1 \mathrm{~cm}^{3}$ of DMSO $\left(24 \mathrm{~h}, 1400 \mathrm{rpm}, 22{ }^{\circ} \mathrm{C}\right)$. A $9 \mathrm{~cm}^{3}, 5 \%(w / v)$ aqueous solution of DMSO was added to the obtained solution, which yielded the final extract concentration of $10 \mathrm{mg} / \mathrm{cm}^{3}$. The samples prepared in this manner were mixed for $1 \mathrm{~h}$ to dissolve the extract. Afterwards, the samples were filtered through a cellulose filter and used for analyses or stored at $4{ }^{\circ} \mathrm{C}$ until further analyses.

\subsection{Determination of Total Polyphenol Content}

The total polyphenol content (TPC) was measured using a modified method described by Singleton and Rossi [25]. Briefly, $0.1 \mathrm{~cm}^{3}$ of extract, $0.5 \mathrm{~cm}^{3}$ of Folin-Ciocalteu reagent and $0.4 \mathrm{~cm}^{3}$ of $7.5 \%(w / v)$ aqueous sodium carbonate solution were added to $5 \mathrm{~cm}^{3}$ Eppendorf tubes. Samples were degassed by vigorous mixing (IKA MS3 basic). After $30 \mathrm{~min}$ incubation in the dark, counted from the moment sodium carbonate solution was added, absorbance was measured at $\lambda=756 \mathrm{~nm}$ (Beckman DU 650 spectrophotometer, Fullerton, CA, USA). The results were expressed as gallic acid equivalent (mg GAE/g d.m. of extract). 


\subsection{Determination of Total Flavonoid Content}

The total flavonoid content (TFC) was measured using the method described by Lamaison and Carnat [26]. Briefly, $0.4 \mathrm{~cm}^{3}$ of extract and $0.8 \mathrm{~cm}^{3}$ of $2 \%(w / v) \mathrm{AlCl}_{3} \times 6 \mathrm{H}_{2} \mathrm{O}$ methanol solution were added to $2 \mathrm{~cm}^{3}$ Eppendorf tubes. After $10 \mathrm{~min}$ of incubation in the dark, counted from the moment the complexing reagent $\left(\mathrm{AlCl}_{3} \times 6 \mathrm{H}_{2} \mathrm{O}\right)$ was added, absorbance was measured at $\lambda=430 \mathrm{~nm}$ (Beckman DU 650 spectrophotometer). The results were determined as quercetin equivalent $(\mathrm{QE})$ and expressed in $\mathrm{mg} \mathrm{QE} / \mathrm{g}$ d.m. of extract.

\subsection{Antioxidant Capacity Assay (DPPH Test)}

The radical scavenging activity was determined using a modified method described by Blois [27]. To $2 \mathrm{~cm}^{3}$ Eppendorf tubes, $1 \mathrm{~cm}^{3}$ of extract solution and $1 \mathrm{~cm}^{3}$ of DPPH radical solution $(0.05 \mathrm{mM})$ were added. After $30 \mathrm{~min}$ incubation in the dark, counted from the moment DPPH was added, absorbance at $\lambda=517 \mathrm{~nm}$ was measured. The results were expressed as Trolox equivalent antioxidant capacity (mg Trolox/g d.m. of extract).

\subsection{Fourier Transform Infrared Spectroscopy (QATR-FTIR) Analysis}

Spectroscopic measurements were performed by an attenuated total reflectance (ATR) method. The transmittance of plant extract samples (5-6 mg) was measured using a FTIR (IRSpirit-T, Schimadzu, Duisburg, Germany) spectrometer equipped with a QATR-S accessory with a diamond crystal and a DLATGS detector with a germanium-coated $\mathrm{KBr}$ beam splitter. Each sample was scanned 25 times within the wavelength range of 4000.0 to $400.0 \mathrm{~cm}^{-1}$ at the resolution of $4.0 \mathrm{~cm}^{-1}$ using the Happ-Genzel function. Sample spectra obtained with the application of LabSolutions IR software (ver. 2.23, Shimadzu, Duisburg, Germany) were corrected, smoothed with the seven-point Savitzky-Golay algorithm and normalized.

\subsection{Statistical Analysis}

All analyses were carried out in triplicate. The results were expressed as mean values \pm standard deviation (SD). The same letter indicated results that were not statistically different within the parameter under analysis, Bonferroni ANOVA test, $p<0.05$. A multidimensional principal component analysis (PCA) with varimax rotation was also applied. All analyses were performed using the STATISTICA, ver. 13.3 (TIBCO Software Inc., Palo Alto, CA, USA).

\section{Results and Discussion}

\subsection{Total Polyphenols and Flavonoids}

Phenolic compounds are essential for plant functions because they are involved in oxidative stress reactions, defensive systems, growth and development [28]. The problem with phenolic compound definition, classification and chemical characterization was presented in a review by Quideau et al. [29]. It has already been shown that raffinate obtained after extraction of polyphenols using $\mathrm{scCO}_{2}$ could be used as a stable and valuable substrate in a biorefinery or for energy production [22]. The $\mathrm{scCO}_{2}$ extraction removes significant amounts of lipids, terpenes, steroids and resin acids that easily undergo autoxidation, which consequently improves both the quality of biofuel and pyrolysis [30-32]. The results of the current study indicate varied polyphenol content in extracts obtained during a oneyear-long experiment depending on both the harvest period and the extraction conditions (Table 1). The aim of crop harvesting at different times was to compare the obtained extract activities in relation to the biomass harvest time and to demonstrate the plant's ability to regrow after harvest at different times of the year (in different growth phases). The study presented in this paper focused only on assessing extract activity. To the best of the authors' knowledge, there is limited information on polyphenols from other analyzed biomasses. The highest polyphenol content $(p<0.05)$ was obtained in the $\mathrm{scCO}_{2} / \mathrm{H}_{2} \mathrm{O}$ extract from S. pectinata (168.18 $\pm 6.26 \mathrm{mg} \mathrm{GAE} / \mathrm{g} \mathrm{d}$.m.) harvested in June, i.e., at the beginning of the vegetation period, while the lowest content was noted for the extract of M. giganteus straw 
harvested in February, obtained by extraction using only $\mathrm{scCO}_{2}(1.24 \pm 0.06 \mathrm{mg}$ GAE $/ \mathrm{g}$ d.m. of the extract). For most of the analyzed extract samples $\left(\mathrm{scCO}_{2}\right.$ or $\left.\mathrm{scCO}_{2} / \mathrm{H}_{2} \mathrm{O}\right)$ obtained from biomass harvested during the growing period, a statistically significantly higher polyphenol content was noted than those for the semi-wood or straw samples collected in February. Only the extracts from S. perfoliatum semi-wood biomass $\left(\mathrm{scCO}_{2}\right)$ and $H$. tuberosus, $M . \times$ giganteus straw $\left(\mathrm{scCO}_{2} / \mathrm{H}_{2} \mathrm{O}\right)$ were characterized by higher polyphenol content than the extracts from biomass harvested during the growing period $(p=0.05)$ (Tables 1 and S1). In another study, the highest polyphenol content in an ethanol extract of Jerusalem artichoke leaves was 4.5-5.7 mg GAE/g d.m. [33], i.e., approximately 2-6-fold lower than the polyphenol content in a supercritical extract of biomass of this species in the current study (Table 1). The contents of polyphenols in $\mathrm{scCO}_{2} / \mathrm{H}_{2} \mathrm{O}$ extracts from $H$. salicifolius and $H$. tuberosus obtained by Malm et al. [23] under the same conditions were similar to those reported in the present study, i.e., the values were lower for the former (13.75 mg GAE/g of extract) and higher for the latter (33.06 mg GAE/g of extract) plant.

Table 1. Influence of extraction conditions $\left(\mathrm{scCO}_{2}\right.$ or $\left.\mathrm{scCO}_{2} / \mathrm{H}_{2} \mathrm{O}\right)$ and harvest time ((A) June, (B) October and (C) February) on total polyphenol content (TPC)* in extracts from herbaceous species.

\begin{tabular}{|c|c|c|c|c|c|c|}
\hline \multirow{3}{*}{ Plant Material } & \multicolumn{6}{|c|}{ TPC (mg GAE/g d.m.) } \\
\hline & \multicolumn{3}{|c|}{$\mathrm{scCO}_{2}$} & \multicolumn{3}{|c|}{$\mathrm{scCO}_{2} / \mathrm{H}_{2} \mathrm{O}$} \\
\hline & $\mathbf{A}$ & B & $\mathrm{C}$ & $\mathbf{A}$ & B & $\mathrm{C}$ \\
\hline Helianthus salicifolius & $20.22 \pm 0.20^{\mathrm{d}}$ & $25.02 \pm 0.31^{\mathrm{a}}$ & $11.92 \pm 0.16^{\mathrm{i}}$ & $27.51 \pm 0.11^{\mathrm{h}}$ & $36.08 \pm 0.15^{g}$ & $15.2 \pm 0.62^{j}$ \\
\hline Silphium perfoliatum & $11.33 \pm 0.07^{j}$ & $13.99 \pm 0.24^{h}$ & $17.37 \pm 0.54^{\mathrm{f}}$ & $58.37 \pm 1.11^{\mathrm{e}}$ & $21.59 \pm 0.15^{\mathrm{i}}$ & $18.25 \pm 0.32^{i, j}$ \\
\hline Helianthus tuberosus & $16.50 \pm 0.06^{g}$ & $16.01 \pm 0.23 \mathrm{~g}$ & $8.47 \pm 0.11^{\mathrm{k}}$ & $27.57 \pm 0.38^{h}$ & $18.34 \pm 0.23^{\mathrm{i}, \mathrm{j}}$ & $26.26 \pm 0.36^{h}$ \\
\hline Miscanthus $\times$ giganteus & $22.17 \pm 0.18^{c}$ & $12.2 \pm 0.19^{\mathrm{i}}$ & $1.24 \pm 0.06^{\mathrm{o}}$ & $73.91 \pm 0.96^{c}$ & $51.33 \pm 0.69^{\mathrm{f}}$ & $90.75 \pm 0.71^{b}$ \\
\hline Miscanthus sinensis & $19.01 \pm 0.20^{\mathrm{e}}$ & $17.11 \pm 0.28^{f}$ & $8.84 \pm 0.35^{\mathrm{k}}$ & $90.98 \pm 2.05^{b}$ & $65.36 \pm 1.26^{\mathrm{d}}$ & $26.61 \pm 0.60^{h}$ \\
\hline Miscanthus sacchariflorus & $19.55 \pm 0.17^{\mathrm{d}, \mathrm{e}}$ & $5.95 \pm 0.23^{1}$ & $4.86 \pm 0.09^{\mathrm{m}}$ & $64.64 \pm 0.97^{\mathrm{d}}$ & $21.91 \pm 0.59^{\mathrm{i}}$ & $14.43 \pm 0.51^{\mathrm{j}}$ \\
\hline Spartina pectinata & $23.93 \pm 0.14^{b}$ & $23.46 \pm 0.22^{b}$ & $3.82 \pm 0.16^{\mathrm{n}}$ & $168.18 \pm 6.26^{\mathrm{a}}$ & $92.47 \pm 1.46^{b}$ & $6.17 \pm 0.07^{k}$ \\
\hline
\end{tabular}

* Mean values of three different determinations followed by standard deviation are presented. The different letters in the same group indicate statistically significant differences between the samples $(p<0.05)$.

A low content of polyphenols was identified in a water extract of the aboveground parts of M. sinensis at the flowering phase $(1.1795 \pm 0.1608 \%$ (\% d.m. equivalent of pyrogallol)) [34]. A high content of polyphenolic compounds is not a prerequisite for the development of a biorefinery concept. Substrates for biotechnological processes with a low polyphenol content or effective methods of polyphenol extraction preceding the bioprocess are often sought. Based on the analysis of cinnamates in the leaves, stems and flowers of $M$. sinensis and $M$. sacchariflorus, it is suggested that an assay could be useful for selecting plants with low contents of antimicrobial phenols that may be a good feedstock for fermentation [35].

Higher contents of polyphenolic compounds were noted in extracts obtained using $\mathrm{scCO}_{2} / \mathrm{H}_{2} \mathrm{O}$ (Figure 1a, marked area, unfilled triangles). The application of this extraction type resulted in an increase in polyphenol content, particularly in the extracts from biomass harvested during the growing period, i.e., in June and October (Table 1). Supercritical fluid extraction is an environment-friendly technology used for the extraction of bioactive compounds from natural products and may provide an alternative to conventional extraction methods. Supercritical fluids exhibit unique characteristics, good solvent properties, a high diffusion coefficient, low viscosity and negligible value of the surface tension coefficient. Modifications of the pressure or temperature produce considerable changes in the fluid properties, including selectivity. These properties enable rapid mass transfer and an increased capability to penetrate the sample matrix, which yields rapid and efficient extraction [36]. The advantage of $\mathrm{scCO}_{2}$ is its ability to produce extracts free of solvent residue. Because $\mathrm{CO}_{2}$ is a gas at ambient temperature and pressure, it is capable of minimizing the thermal degradation of bioactive compounds. Supercritical $\mathrm{CO}_{2}$ is safe for human health and the environment and is reusable, inert, nontoxic, nonflammable and noncorrosive [37]. However, $\mathrm{CO}_{2}$ is a weak solvent for the extraction of polar compounds, 
including polyphenolic compounds. A frequently proposed solution to this problem is the use of a cosolvent, a modifier that changes the solvent properties. For the extraction of polar compounds such as alkaloids, glycosides, saccharides and cyclitols, water and various organic solvents that are soluble in supercritical fluid have been used as a cosolvent, e.g., methanol, ethanol, acetone and acetonitrile. This modification usually requires the adaptation of extraction conditions to the new solvent composition and its critical parameters. The addition of water as a cosolvent modifies the polarity of the mixture and increases the efficiency of extraction of polar polyphenolic compounds. For the first time, $\mathrm{scCO}_{2}$ was used for the extraction of polyphenols from grape marc, but the effective and selective extraction of proanthocyanidins required a $15 \%$ addition of water to the $\mathrm{scCO}_{2}$ [38]. The antioxidant and biocidal properties of extracts obtained from $\mathrm{H}$. salicifolius and $\mathrm{H}$. tuberosus with $\mathrm{scCO}_{2} / \mathrm{H}_{2} \mathrm{O}$ were presented in [23]. Generally, higher contents of polyphenols were obtained in willow and poplar biomass samples after extraction with $\mathrm{scCO}_{2}$ and water compared to extraction with $\mathrm{scCO}_{2}$ alone [24].

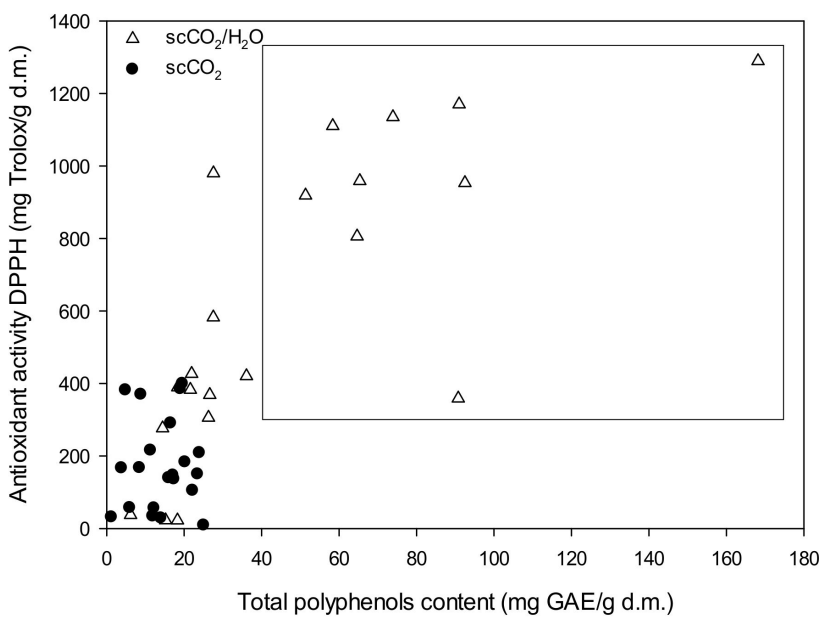

(a)

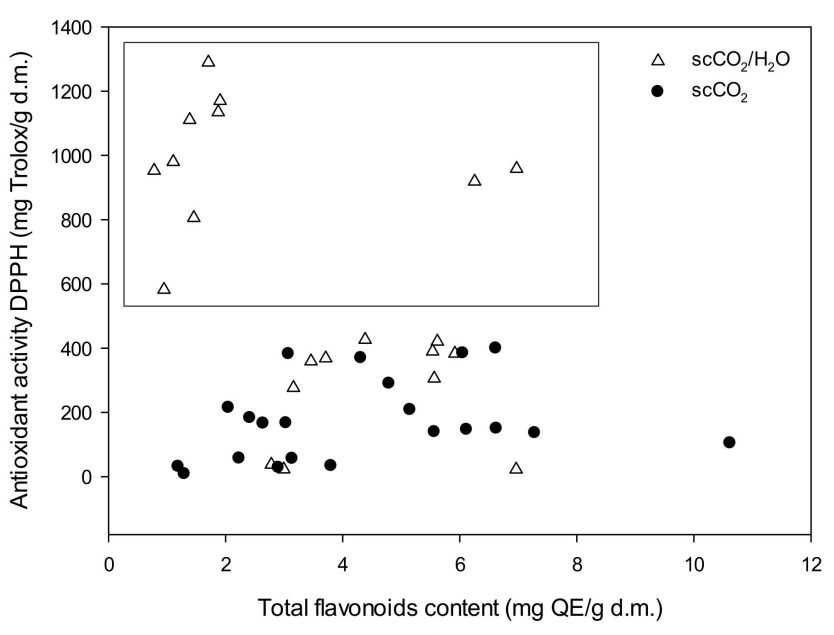

(b)

Figure 1. Interaction between (a) total polyphenol content (TPC), (b) total flavonoid content (TFC) and antioxidant activity determined in $\mathrm{scCO}_{2} / \mathrm{H}_{2} \mathrm{O}(\Delta)$ and $\mathrm{scCO}_{2}(\bullet)$ extracts from perennial herbaceous crops. DPPH - 2,2-diphenyl-1picrylhydrazyl.

The highest TFC was obtained in the $\mathrm{scCO}_{2}$ extract from $M . \times$ giganteus harvested at the beginning of the growing period (June) $(10.62 \pm 0.09 \mathrm{mg}$ QE $/ \mathrm{g} \mathrm{d.m}$.) $(p<0.05)$ (Table 2). The application of $\mathrm{scCO}_{2}$ extraction enabled an increase in flavonoid content compared to extraction using $\mathrm{scCO}_{2} / \mathrm{H}_{2} \mathrm{O}$ when biomass from the beginning of the growing period (June) was used as the substrate. However, when biomass from October and February was used as the extraction substrate, no correlation was found between the solvent used and the selective flavonoid extraction (Table 2 and Figure 1b). Moreover, it was demonstrated that flavonoids from pomelo peel were preferentially separated by $\mathrm{scO}_{2}$ at $80{ }^{\circ} \mathrm{C}$ and a pressure of $39 \mathrm{MPa}$ with $85 \%$ aqueous ethanol as a modifier [39]. The lowest statistically significant $(p<0.05)$ flavonoid content was obtained following extraction using $\mathrm{scCO}_{2} / \mathrm{H}_{2} \mathrm{O}$ from all of the plants harvested at the beginning of the growing period except for S. pectinata (Tables 2 and S2). 
Table 2. Influence of extraction conditions $\left(\mathrm{scCO}_{2}\right.$ or $\left.\mathrm{scCO}_{2} / \mathrm{H}_{2} \mathrm{O}\right)$ and harvest time ((A) June, (B) October and (C) February) on total flavonoid content (TFC)* in extracts from herbaceous species.

\begin{tabular}{|c|c|c|c|c|c|c|}
\hline \multirow{3}{*}{ Plant Material } & \multicolumn{6}{|c|}{ TFC (mg QE/g d.m.) } \\
\hline & \multicolumn{3}{|c|}{$\mathrm{scCO}_{2}$} & \multicolumn{3}{|c|}{$\mathrm{scCO}_{2} / \mathrm{H}_{2} \mathrm{O}$} \\
\hline & A & & $\mathrm{C}$ & A & B & $\mathrm{C}$ \\
\hline Helianthus salicifolius & $2.41 \pm 0.06^{\mathrm{m}}$ & $1.29 \pm 0.07^{\circ}$ & $3.80 \pm 0.04^{\mathrm{i}}$ & $0.95 \pm 0.02^{1, m}$ & $5.62 \pm 0.01^{\mathrm{d}}$ & $2.99 \pm 0.09 \mathrm{~g}, \mathrm{~h}$ \\
\hline Silphium perfoliatum & $2.05 \pm 0.05^{n}$ & $2.90 \pm 0.03^{k}$ & $7.28 \pm 0.09^{b}$ & $1.39 \pm 0.02^{\mathrm{k}}$ & $5.92 \pm 0.05^{c}$ & $6.95 \pm 0.11^{a}$ \\
\hline Helianthus tuberosus & $4.79 \pm 0.02^{g}$ & $5.57 \pm 0.05^{\mathrm{e}}$ & $3.03 \pm 0.11^{\mathrm{j}, \mathrm{k}}$ & $1.11 \pm 0.05^{1}$ & $5.54 \pm 0.04^{\mathrm{d}}$ & $5.56 \pm 0.64^{d}$ \\
\hline Miscanthus $\times$ giganteus & $10.62 \pm 0.09^{a}$ & $3.14 \pm 0.03^{j}$ & $1.19 \pm 0.03^{g}$ & $1.87 \pm 0.03^{\mathrm{i}}$ & $6.25 \pm 0.11^{b}$ & $3.46 \pm 0.06^{f}$ \\
\hline Miscanthus sinensis & $6.05 \pm 0.05^{\mathrm{d}}$ & $6.12 \pm 0.03^{\mathrm{d}}$ & $4.31 \pm 0.01^{\mathrm{h}}$ & $1.91 \pm 0.03^{\mathrm{i}}$ & $6.97 \pm 0.11^{\mathrm{a}}$ & $3.71 \pm 0.12^{f}$ \\
\hline Miscanthus sacchariflorus & $6.61 \pm 0.07^{c}$ & $2.23 \pm 0.02^{\mathrm{m}, \mathrm{n}}$ & $3.07 \pm 0.03 \mathrm{j}, \mathrm{k}$ & $1.46 \pm 0.02^{\mathrm{j}, \mathrm{k}}$ & $4.38 \pm 0.06^{\mathrm{e}}$ & $3.16 \pm 0.07 \mathrm{~g}$ \\
\hline Spartina pectinata & $5.15 \pm 0.11^{\mathrm{f}}$ & $6.62 \pm 0.05^{c}$ & $2.64 \pm 0.06^{1}$ & $1.71 \pm 0.03^{i, j}$ & $0.78 \pm 0.01 \mathrm{~m}$ & $2.78 \pm 0.08^{h}$ \\
\hline
\end{tabular}

${ }^{*}$ Mean values of three different determinations followed by standard deviation are presented. The different letters in the same group indicate statistically significant differences between the samples $(p<0.05)$.

The chemical composition of the studied plants depend on the environmental conditions, growing period, etc. [40]. Changes in the chemical composition affect the biological activity of a plant and the possibility of obtaining active compounds. The effect of the season on the chemical composition, and thus bioactivity, can be attributed to climate change, i.e., the temperature, the soil moisture content, precipitation and the plant growth period [41]. A significant seasonal variation of phenolic compounds was observed in the leaves of Cyclocarya paliurus (Batal.) Iljinskaja, and the highest phenolic content was recorded in May, July and November [42]. A seasonal variation was observed in the synthesis of secondary metabolites in Phillyrea angustifolia, and the highest oleuropein content was confirmed during the winter period [43]. Similarly, Pacifico et al. [44] demonstrated that an extract of Calamintha nepeta harvested during the winter period was characterized by a higher acacetin content. The season can affect the chemical composition of plants in different ways, and the possible changes in the chemical composition can occur over several years. A quantitative analysis of phenolic compounds in extracts of Vaccinium myrtillus demonstrated relatively small seasonal variations in the composition of phenolic compounds or their absence, while significant changes in the composition were observed over two successive years [45].

The availability of water can also impact the synthesis of polyphenolic compounds by the plants. The relationships between the synthesis of polyphenolic compounds by the plants and the hydration are unclear and are determined by their parameters. High temperatures $\left(30-40{ }^{\circ} \mathrm{C}\right)$ can prevent flavonoid synthesis by inhibiting gene expression and enzyme activity [46], while low temperatures can induce flavonoid biosynthesis (although in the absence of light, the synthesis of these compounds is inhibited) [47].

\subsection{Antioxidant Activity}

The extracts obtained using a mixture of $\mathrm{scCO}_{2} / \mathrm{H}_{2} \mathrm{O}$, in which an increased polyphenolic compound content was also noted, exhibited the highest antioxidant activity (Tables 3 and S3, Figure 1a). The highest antioxidant activity $(p<0.05)$ was noted for the extract from S. pectinata (1289.5 $\pm 34.35 \mathrm{mg}$ Trolox/g d.m.) harvested at the beginning of the growing period, and the lowest was in the extract from S. perfoliatum semi-wood biomass (22.85 $\pm 0.62 \mathrm{mg}$ Trolox/g d.m.). Regardless of the biomass species or the extraction technique applied, the extracts obtained from plants harvested in June (the beginning of the growing period) were characterized by the highest antioxidant activity (Table 3). 
Table 3. Influence of extraction conditions $\left(\mathrm{scCO}_{2}\right.$ or $\left.\mathrm{scCO}_{2} / \mathrm{H}_{2} \mathrm{O}\right)$ and harvest time ((A) June, (B) October and (C) February) on antioxidant activity (DPPH assay)* in extracts from herbaceous species.

\begin{tabular}{|c|c|c|c|c|c|c|}
\hline \multirow{3}{*}{ Plant Material } & \multicolumn{6}{|c|}{ Antioxidant Activity Using the DPPH Method (mg Trolox/g d.m.) } \\
\hline & & $\mathrm{scCO}_{2}$ & & & $\mathrm{scCO}_{2} / \mathrm{H}_{2} \mathrm{O}$ & \\
\hline & A & B & C & A & B & C \\
\hline Helianthus salicifolius & $183.04 \pm 7.77^{\mathrm{f}}$ & $9.04 \pm 1.95^{n}$ & $34.02 \pm 0.21 \mathrm{~m}$ & $582.50 \pm 34.76^{\mathrm{h}}$ & $420.78 \pm 2.94^{\mathrm{i}}$ & $23.01 \pm 0.13^{n}$ \\
\hline Silphium perfoliatum & $215.55 \pm 4.54^{\mathrm{e}}$ & $28.62 \pm 1.01^{\mathrm{m}}$ & $136.47 \pm 0.59^{j}$ & $1110.64 \pm 47.27^{\mathrm{c}}$ & $383.25 \pm 3.17^{\mathrm{j}, \mathrm{k}}$ & $22.85 \pm 0.62^{n}$ \\
\hline Helianthus tuberosus & $290.43 \pm 2.25^{\mathrm{d}}$ & $139.48 \pm 4.82^{i, j}$ & $167.18 \pm 2.25 \mathrm{~g}$ & $980.24 \pm 25.15^{\mathrm{d}}$ & $389.94 \pm 0.51^{j}$ & $305.99 \pm 0.67^{1}$ \\
\hline Miscanthus $\times$ giganteus & $104.83 \pm 2.97^{k}$ & $56.31 \pm 1.52^{\mathrm{i}}$ & $31.56 \pm 0.24^{\mathrm{m}}$ & $1134.86 \pm 33.73^{c}$ & $919.02 \pm 1.48^{\mathrm{f}}$ & $359.16 \pm 20.86^{k}$ \\
\hline Miscanthus sinensis & $384.94 \pm 5.52^{b}$ & $146.69 \pm 1.20^{\mathrm{h}, \mathrm{i}}$ & $369.83 \pm 3.76^{c}$ & $1170.19 \pm 17.96^{b}$ & $958.81 \pm 1.87^{\mathrm{d}, \mathrm{e}}$ & $368.78 \pm 5.65^{\mathrm{j}, \mathrm{k}}$ \\
\hline Miscanthus sacchariflorus & $399.41 \pm 2.67^{a}$ & $57.20 \pm 4.56^{\mathrm{i}}$ & $382.05 \pm 2.67^{\mathrm{a}}$ & $805.72 \pm 31.51^{\mathrm{g}}$ & $426.86 \pm 1.94^{\mathrm{i}}$ & $276.91 \pm 2.10^{\mathrm{m}}$ \\
\hline Spartina pectinata & $208.44 \pm 5.21^{\mathrm{e}}$ & $150.07 \pm 2.74^{\mathrm{h}}$ & $166.43 \pm 0.85 \mathrm{~g}$ & $1289.50 \pm 34.35^{\mathrm{a}}$ & $953.15 \pm 1.66^{\mathrm{e}}$ & $37.85 \pm 0.16^{n}$ \\
\hline
\end{tabular}

* Mean values of three different determinations followed by standard deviation are presented. The different letters in the same group indicate statistically significant differences between the samples $(p<0.05)$. DPPH - 2,2-diphenyl-1-picrylhydrazyl.

The accumulation, quantity and activity of phenolic compounds in the plant raw material are determined by the previously mentioned factors, primarily the substrate, plant species, the method of biomass preparation and the growth conditions. Antioxidant activity is primarily determined by the content of bioactive phenolic compounds. The current study found a positive correlation between the polyphenolic compound content and the antioxidant activity $(r=0.80)$, regardless of the type of raw material, the harvest date or the extraction conditions. In other studies, the antioxidant activity was closely related to the TPC and TFC in Nyctanthes arbor-tristis (Harsingar) leaf extracts used in Indian traditional medicine [48]. Zhang et al. [49] analyzed differences in the contents of polyphenols and flavonoids as well as the antioxidant activity in pomegranate leaves. In the period between April and September, the polyphenol and flavonoid contents decreased and then gradually increased. The antioxidant activity of extracts was also significantly correlated with the polyphenolic compound content $(\mathrm{r}=0.80)$.

In the extracts obtained using $\mathrm{scCO}_{2} / \mathrm{H}_{2} \mathrm{O}$, a high polyphenol content of over $40 \mathrm{mg}$ GAE/g d.m. was obtained from S. perfoliatum and M. sacchariflorus harvested in June, from M. sinensis and S. pectinata harvested during the growing period (June and October) and from $M . \times$ giganteus harvested at each of the analyzed dates (Figure 1a). No statistical relationship was found between TFC and antioxidant activity (Figure 1b). The antioxidant activity over $600 \mathrm{mg}$ Trolox $/ \mathrm{g} \mathrm{d} . \mathrm{m}$. was obtained for extracts with a flavonoid content of approximately 2, or over $6 \mathrm{mg} \mathrm{QE} / \mathrm{g} \mathrm{d}$.m. (Figure $1 \mathrm{~b}$, marked area, unfilled triangles). The $\mathrm{scCO}_{2}$ extract with the highest flavonoid content (from $M . \times$ giganteus) from biomass obtained at the beginning of the growing period (June) was characterized by a low antioxidant activity of 104.83 Trolox/g d.m. Therefore, it can be initially concluded that it is the qualitative composition rather than the content that probably determines the antioxidant activity.

The principal components $\mathrm{PC} 1$ and $\mathrm{PC} 2$ for extracts obtained using $\mathrm{scCO}_{2}$ (Figure 2a) or $\mathrm{scCO}_{2} / \mathrm{H}_{2} \mathrm{O}$ (Figure 2b) explained $86.5 \%$ (53.8\% and $32.7 \%$ ) and $91.5 \%(68.3 \%$ and $23.2 \%)$ of data sets, respectively. However, a great dispersion of the results based on the previous analyses was noticeable. PC1 represents TPC and the PC2 represents antioxidant activity (DPPH). The TPC and TFC values in the extracts obtained using $\mathrm{scCO}_{2}$ were positively correlated with the antioxidant activity (Figure 2a). A negative correlation for TFC and a positive correlation for TPC were demonstrated with the antioxidant activity in the extracts obtained using $\mathrm{scCO}_{2}$ and water. 


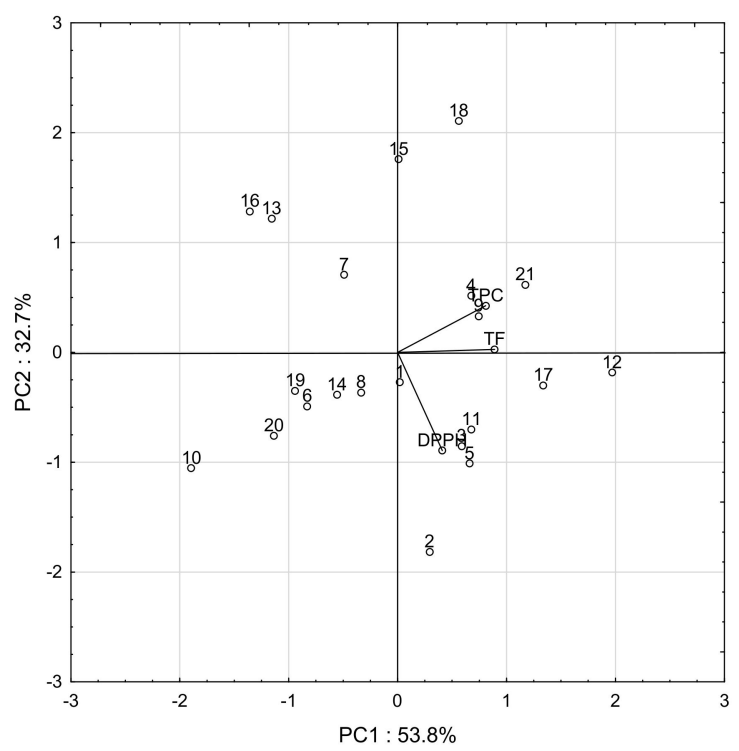

(a)

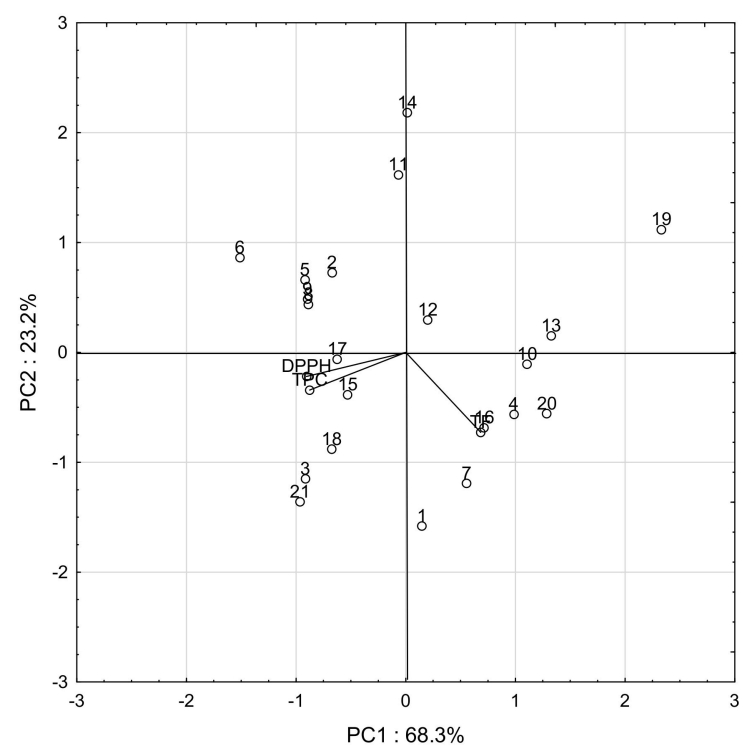

(b)

Figure 2. Principal component analysis of total polyphenol content (TPC), total flavonoid content (TFC) and antioxidant activity (DPPH) of extracts obtained with (a) $\mathrm{scCO}_{2}$ or $(\mathbf{b}) \mathrm{scCO}_{2} / \mathrm{H}_{2} \mathrm{O}$. Points 1-21 present samples obtained from Helianthus salicifolius, Silphium perfoliatum, Helianthus tuberosus, Miscanthus $\times$ giganteus, Miscanthus sacchariflorus, Miscanthus sinensis and Spartina pectinate harvested in June (A), October (B) and February (C).

There are many parameters that influence this assay of antioxidant capacity. Lignin is a polymer constructed of aromatic subunits that account for its radical scavenging activity and was not analyzed in the studied samples [50]. A high content of lignin was determined in an extract from $M . \times$ giganteus and Panicum virgatum $L$. obtained by different methods in [51]. The presence of residual carbohydrates as well as aliphatic hydroxyls, along with lignin structural monomers, can cause an overestimation of antioxidant capacity.

\subsection{FTIR Analysis}

Selected extracts $\left(\mathrm{scCO}_{2}\right.$ and $\left.\mathrm{scCO}_{2} / \mathrm{H}_{2} \mathrm{O}\right)$ from the plants harvested in June and characterized by a high content of phenolic compounds were used for the identification of functional groups present in extract components. Peak characteristic of functional group bonds in FTIR spectra were identified (Figures S1-S14 and Table S4), classified into nine types groups and assigned a functional group based on data presented in the literature (Table 4) [52-57]. An analysis of FTIR spectra indicated absorption within the wavelength region corresponding to vibrations of bonds present in the principal components of lignocellulose biomass, i.e., saccharides, lignins, proteins and lipids. Absorption within the wavelength region from 3421 to $3335 \mathrm{~cm}^{-1}$, characteristic of $\mathrm{O}-\mathrm{H}$ and $\mathrm{N}-\mathrm{H}$ stretching bonds occurring in saccharides, proteins and polyphenols (Table 4) [55-57], was noted in $\mathrm{scCO}_{2}$ and $\mathrm{scCO}_{2} / \mathrm{H}_{2} \mathrm{O}$ extracts from $H$. salicifolius, $H$. tuberosus and $M$. sinensis, $\mathrm{scCO}_{2}$ extracts from $M . \times$ giganteus and $\mathrm{scCO}_{2} / \mathrm{H}_{2} \mathrm{O}$ extracts from S. perfoliatum and S. pectinata. All of the examined extracts displayed absorption within the wavelength region from 3070 to $2849 \mathrm{~cm}^{-1}$, corresponding to vibrations of the $\mathrm{C}-\mathrm{H}$ stretching bonds present in the functional groups of $\mathrm{CH}_{2}$ and $\mathrm{CH}_{3}$ as well as in aromatic rings and the $\mathrm{O}-\mathrm{CH}_{3}$ bonds in lipids, lignins, saccharides and esters (Table 4) [52-57]. The existence of ester bonds in all of the studied extracts was confirmed by the excitation in the wavelength region from 1748 to $1648 \mathrm{~cm}^{-1}$, which corresponds to polyesters and lignins (Table 4) [55-57]. This region is also characteristic of vibrations of the $\mathrm{C}-\mathrm{N}$ stretching bonds present in proteins and the unconjugated cis $\mathrm{C}=\mathrm{C}$ bonds in alkenyl groups (Table 4) $[52,54,57]$. The FTIR spectra of scCO ${ }_{2}$ extracts from $\mathrm{H}$. salicifolius, $\mathrm{scCO}_{2}$ and $\mathrm{scCO}_{2} / \mathrm{H}_{2} \mathrm{O}$ extracts from $\mathrm{H}$. tuberosus and $\mathrm{scCO}_{2} / \mathrm{H}_{2} \mathrm{O}$ extracts from $S$. pectinata displayed absorbance within the wavelength region 
from 1602 to $1514 \mathrm{~cm}^{-1}$, corresponding to vibrations of the $\mathrm{C}-\mathrm{C}$ and $\mathrm{C}=\mathrm{C}$ stretching bonds occurring in aromatic rings and the $\mathrm{COO}^{-}$stretching bonds in phenols, pectins and lignins (Table 4) $[53,55,56]$.

Table 4. Identification of functional groups of supercritical plant extracts $\left(\mathrm{scCO}_{2}\right.$ and $\left.\mathrm{scCO}_{2} / \mathrm{H}_{2} \mathrm{O}\right)$ harvested in June (analysis based on literature [52-57]).

\begin{tabular}{|c|c|c|c|c|c|}
\hline \multirow{2}{*}{ Group } & \multirow{2}{*}{$\begin{array}{l}\text { Wavenumbers } \\
\left(\mathrm{cm}^{-1}\right)\end{array}$} & \multicolumn{2}{|c|}{ Plant Extract } & \multirow{2}{*}{ Bond Type } & \multirow{2}{*}{ Functional Group } \\
\hline & & $\mathrm{scCO}_{2}$ & $\mathrm{scCO}_{2} / \mathrm{H}_{2} \mathrm{O}$ & & \\
\hline 1 & $4000-3100$ & $\begin{array}{l}\text { H. salicifolius, } H . \text { tuberosus, } \\
\text { M. } \times \text { giganteus, } M . \text { sinensis }\end{array}$ & $\begin{array}{c}\text { H. salicifolius, S. perfoliatum, } \\
\text { H. tuberosus, M. sinensis, } \\
\text { S. pectinata }\end{array}$ & $\mathrm{O}-\mathrm{H}, \mathrm{N}-\mathrm{H}$ stretching & $\begin{array}{c}\text { Polyphenolic, } \\
\text { carbohydrates, } \\
\text { proteins }\end{array}$ \\
\hline 2 & $3100-2800$ & $\begin{array}{l}\text { H. salicifolius, S. perfoliatum, } \\
\text { H. tuberosus, } M . \times \text { giganteus, } \\
\text { M. sinensis, M. sacchariflorus, } \\
\text { S. pectinata }\end{array}$ & $\begin{array}{l}\text { H. salicifolius, S. perfoliatum, } \\
\text { H. tuberosus, } M . \times \text { giganteus, } \\
\text { M. sinensis, M. sacchariflorus, } \\
\text { S. pectinata }\end{array}$ & $\begin{array}{l}\mathrm{C}-\mathrm{H} \text { stretching in } \\
\mathrm{CH}_{2} \text { and } \mathrm{CH}_{3} ; \\
\mathrm{C}-\mathrm{H} \text { aromatic } \\
\text { stretching; } \mathrm{O}-\mathrm{CH}_{3}\end{array}$ & $\begin{array}{l}\text { Lipids, lignins, } \\
\text { carbohydrates, esters }\end{array}$ \\
\hline 3 & $1750-1650$ & $\begin{array}{l}\text { H. salicifolius, } \text { S. perfoliatum, } \\
\text { H. tuberosus, } M . \times \text { giganteus, } \\
\text { M. sinensis, M. sacchariflorus, } \\
\text { S. pectinata }\end{array}$ & $\begin{array}{l}\text { H. salicifolius, S. perfoliatum, } \\
\text { H. tuberosus, } M . \times \text { giganteus, } \\
\text { M. sinensis, M. sacchariflorus, } \\
\text { S. pectinata }\end{array}$ & $\begin{array}{l}\mathrm{C}=\mathrm{O} \text { ester stretching; } \\
\mathrm{C}-\mathrm{N} \text { stretching; } \\
\text { cis } \mathrm{C}=\mathrm{C} \text { unconjugated }\end{array}$ & $\begin{array}{l}\text { Polyesters, lignins, } \\
\text { proteins, } \\
\text { alkenyl groups }\end{array}$ \\
\hline 4 & $1610-1500$ & - & $\begin{array}{l}\text { H. salicifolius, S. perfoliatum, } \\
\text { H. tuberosus, S. pectinata }\end{array}$ & $\begin{array}{l}\mathrm{C}-\mathrm{C}, \mathrm{C}=\mathrm{C} \text { aromatic } \\
\text { stretching; } \\
\mathrm{COO}^{-} \text {stretching }\end{array}$ & $\begin{array}{l}\text { Phenolic groups, } \\
\text { pectins, lignins }\end{array}$ \\
\hline 5 & $1500-1290$ & $\begin{array}{l}\text { H. salicifolius, S. perfoliatum, } \\
\text { H. tuberosus, } M . \times \text { giganteus, } \\
\text { M. sinensis, M. sacchariflorus, } \\
\text { S. pectinata }\end{array}$ & $\begin{array}{c}\text { H. salicifolius, } \text { S. perfoliatum, } \\
\text { H. tuberosus, } M . \times \text { giganteus, } \\
\text { M. sinensis, M. sacchariflorus, } \\
\text { S. pectinata }\end{array}$ & $\begin{array}{c}\mathrm{CH}_{2} \text { scissoring, } \\
\text { bending, out of plane; } \\
\mathrm{C}-\mathrm{H} \text { in }>\mathrm{CH}-; \mathrm{C}-\mathrm{H} \\
\text { in }-\mathrm{CH}_{3} ; \\
\mathrm{C}-\mathrm{H}, \mathrm{CH}_{2}, \mathrm{CH}_{3} \\
\text { deformations; } \\
\mathrm{C}=\mathrm{C}-\mathrm{C} \text { aromatic ring } \\
\text { stretching; } \\
\mathrm{O}-\mathrm{H} \text { bending; } \mathrm{N}-\mathrm{H} \text {, } \\
\text { C-N }\end{array}$ & $\begin{array}{c}\text { triterpenoids, phenyl } \\
\text { groups, } \\
\text { polysaccharides, } \\
\text { pectins, lipids, } \\
\text { lignins, tertiary } \\
\text { alcohols, proteins }\end{array}$ \\
\hline 6 & $1260-1100$ & $\begin{array}{c}\text { H. salicifolius, } \text { S. perfoliatum, } \\
\text { H. tuberosus, } M . \times \text { giganteus, } \\
\text { M. sinensis, M. } \\
\text { sacchariflorus, S. pectinata }\end{array}$ & $\begin{array}{l}\text { H. salicifolius, } \text { S. perfoliatum, } \\
\text { H. tuberosus, } M . \times \text { giganteus, } \\
\text { M. sinensis, M. sacchariflorus, } \\
\text { S. pectinata }\end{array}$ & $\begin{array}{l}\mathrm{C}-\mathrm{O}, \mathrm{C}-\mathrm{N}, \mathrm{C}-\mathrm{C}, \\
>\mathrm{PO}_{2} \text { stretching; } \\
\mathrm{O}-\mathrm{H} \text { bending; } \mathrm{C}-\mathrm{O} \\
\text { ring vibrations }\end{array}$ & $\begin{array}{l}\text { Phenyl groups, } \\
\text { lignins, pectins, } \\
\text { triterpenoids, } \\
\text { polysaccharides, } \\
\text { phospholipids, } \\
\text { proteins }\end{array}$ \\
\hline 7 & $1100-1000$ & $\begin{array}{c}\text { H. salicifolius, } S . \text { perfoliatum, } \\
\text { H. tuberosus, } M . \times \text { giganteus, } \\
\text { M. sinensis, M. sacchariflorus, } \\
\text { S. pectinata }\end{array}$ & $\begin{array}{l}\text { H. salicifolius, } \text { S. perfoliatum, } \\
\text { H. tuberosus, } M . \times \text { giganteus, } \\
\text { M. sinensis, M. sacchariflorus, } \\
\text { S. pectinata }\end{array}$ & $\begin{array}{c}\mathrm{C}-\mathrm{O}, \mathrm{C}-\mathrm{N} \text { stretching; } \\
\mathrm{C}-\mathrm{H} \text { aromatic } \\
\text { stretching; }>\mathrm{PO}_{2} \\
\text { stretching }\end{array}$ & $\begin{array}{l}\text { Phenolic groups, } \\
\text { phospholipids, } \\
\text { polysaccharides, } \\
\text { pectins, } \\
\text { aliphatic amines }\end{array}$ \\
\hline 8 & $1000-510$ & $\begin{array}{c}\text { H. salicifolius, } \text { S. perfoliatum, } \\
\text { H. tuberosus, } M . \times \text { giganteus, } \\
\text { M. sinensis, M. sacchariflorus, } \\
\text { S. pectinata }\end{array}$ & $\begin{array}{l}\text { H. salicifolius, } H . \text { tuberosus, } \\
\text { M. } \times \text { giganteus, M. sinensis, } \\
\text { M. sacchariflorus, S. pectinata }\end{array}$ & $\begin{array}{c}\mathrm{C}-\mathrm{H} \text { aromatic } \\
\text { stretching; }-\mathrm{CH}_{2}-; \\
-\mathrm{HC}-; \\
\text { cis }-\mathrm{CH} \text {; trans } \mathrm{C}-\mathrm{H} \\
\text { out of plane }\end{array}$ & Isoprenoids \\
\hline 9 & $510-400$ & H. salicifolius, H. tuberosus & H. tuberosus, S. pectinata & $\begin{array}{l}\mathrm{S}-\mathrm{S} \text { stretching; } \\
\mathrm{C}-\mathrm{OH}_{3} \text { torsion }\end{array}$ & $\begin{array}{l}\text { Aryl disulfides, } \\
\text { polysulfides, } \\
\text { methoxy groups }\end{array}$ \\
\hline
\end{tabular}

An excitation within the wavelength region from 1464 to $1291 \mathrm{~cm}^{-1}$ was recorded for all of the analyzed extracts, which confirms the presence of the functional groups occurring in the compounds, including triterpenoids, polysaccharides, pectins, lignins, lipids, tertiary alcohols, proteins and phenols (Table 4) [52-57]. The largest number of peaks within this wavelength region was noted for $\mathrm{scCO}_{2}$ extracts from S. perfoliatum $(1464,1445,1377,1310$ and $1291 \mathrm{~cm}^{-1}$ ), while the lowest number of peaks was recorded for $\mathrm{scCO}_{2} / \mathrm{H}_{2} \mathrm{O}$ extracts from $H$. tuberosus $\left(1374 \mathrm{~cm}^{-1}\right)$. Vibrations of the $\mathrm{C}-\mathrm{O}, \mathrm{C}-\mathrm{N}, \mathrm{C}-\mathrm{C}$ and $>\mathrm{PO}_{2}$ stretching bonds, $\mathrm{O}-\mathrm{H}$ bending bonds and aromatic $\mathrm{C}-\mathrm{O}$ bonds (Table 4) [52-57] within the wavelength from 1271 to $1117 \mathrm{~cm}^{-1}$, occurring in triterpenoids, phospholipids, polysaccharides, pectins, 
lignins, proteins and phenolic groups, were detected in all extract samples. However, for extracts obtained from $M$. sinensis, $M . \times$ giganteus and $M$. sacchariflorus, only one peak was detected (approximately $1170 \mathrm{~cm}^{-1}$ ) regardless of the solvent used. Excitation within the region from 1104 to $1013 \mathrm{~cm}^{-1}$, caused by vibrations of the $\mathrm{C}-\mathrm{O}, \mathrm{C}-\mathrm{N}$ and $>\mathrm{PO}_{2}$ stretching bonds and aromatic $\mathrm{C}-\mathrm{H}$ stretching bonds characteristic of phospholipids, polysaccharides, pectins, aliphatic amines and phenols (Table 4) [54-57], was recorded in all analyzed extracts. The FTIR spectra indicated that the number of excitations recorded for isoprenoid bonds was greater for $\mathrm{scCO}_{2}$ extracts than for $\mathrm{scCO}_{2} / \mathrm{H}_{2} \mathrm{O}$ extracts, and this was the case for all the analyzed extracts except for extracts from S. pectinata. The $\mathrm{scCO}_{2} / \mathrm{H}_{2} \mathrm{O}$ extract from S. perfoliatum did not display the presence of isoprenoids. Within the wavelength region from 501 to $427 \mathrm{~cm}^{-1}$, absorbance corresponding to vibrations of the S-S stretching bonds and $\mathrm{C}-\mathrm{OH}_{3}$ torsion bonds occurring in polysulfides, aryl disulfides and methoxy groups (Table 4) [52,53] was detected for extracts from H. salicifolius $\left(\mathrm{scCO}_{2}\right), H$. tuberosus $\left(\mathrm{scCO}_{2}\right.$ or $\left.\mathrm{scCO}_{2} / \mathrm{H}_{2} \mathrm{O}\right)$ and S. pectinata $\left(\mathrm{scCO}_{2} / \mathrm{H}_{2} \mathrm{O}\right)$.

\section{Conclusions}

The presented data indicate varying contents of polyphenolic compounds in the biomass extracts of perennial herbaceous crops depending on the harvest term in the growing period. The varying quality of extract compositions determined by FTIR analysis was noted, which depended on the performance of extraction using $\mathrm{scCO}_{2}$ or the same supercritical solvent combined with water. This information can enable the utilization of the studied biomass for not only the production of bioenergy but also to obtain valuable components of foodstuffs, medicines and cosmetics. However, a comprehensive analysis of the properties and chemical composition (particularly the flavonoid content) of the extracts as well as the relationship between the composition and the properties of the extracts is necessary. Moreover, it is important to study the influence of the extracts on microorganisms and enzymes to determine the cytotoxicity, apoptotic effect and safety of their use. Further development of selective techniques for the extraction of polyphenols, hydrocarbons, fatty acids and acylglycerols from biomass (particularly using $\mathrm{scCO}_{2}$ ) or of the extract fractioning method is also possible.

Supplementary Materials: The following are available online at https:/ /www.mdpi.com/article/10 .3390 /agriculture11060488/s1, Table S1. The results of ANOVA $(\mathrm{p}<0.05)$ for the influence of substrate, extraction conditions and harvest time (A) June, (B) October, (C) February on total polyphenol concentration (TPC), Table S2. The results of ANOVA $(p<0.05)$ for the influence of substrate, extraction conditions and harvest time (A) June, (B) October, (C) February on total flavonoid concentration (TFC), Table S3. The results of ANOVA $(\mathrm{p}<0.05)$ for the influence of substrate, extraction conditions and harvest time (A) June, (B) October, (C) February on antioxidant activity (DPPH assay), Table S4. Wavenumbers of QATR-FTIR peaks of supercritical plant extracts $\left(\mathrm{scCO}_{2}\right.$ and $\left.\mathrm{scCO}_{2} / \mathrm{H}_{2} \mathrm{O}\right)$ harvested in June, Figure S1. QATR-FTIR spectrum of the $\mathrm{scCO}_{2}$ extract from H. salicifolius harvested in June, Figure S2. QATR-FTIR spectrum of the $\mathrm{scCO}_{2} / \mathrm{H}_{2} \mathrm{O}$ extract from $H$. salicifolius harvested in June, Figure S3. QATR-FTIR spectrum of the $\mathrm{scCO}_{2}$ extract from S. perfoliatum harvested in June, Figure S4. QATR-FTIR spectrum of the $\mathrm{scCO}_{2} / \mathrm{H}_{2} \mathrm{O}$ extract from $S$. perfoliatum harvested in June, Figure S5. QATR-FTIR spectrum of the $\mathrm{scCO}_{2}$ extract from $\mathrm{H}$. tuberosus harvested in June, Figure S6. QATRFTIR spectrum of the $\mathrm{scCO}_{2} / \mathrm{H}_{2} \mathrm{O}$ extract from $\mathrm{H}$. tuberosus harvested in June, Figure S7. QATRFTIR spectrum of the $\mathrm{scCO}_{2}$ extract from $M . \times$ giganteus harvested in June, Figure S8. QATR-FTIR spectrum of the $\mathrm{scCO}_{2} / \mathrm{H}_{2} \mathrm{O}$ extract from $M . \times$ giganteus harvested in June, Figure S9. QATR- FTIR spectrum of the $\mathrm{scCO}_{2}$ extract from $M$. sinensis harvested in June, Figure S10. QATR-FTIR spectrum of the $\mathrm{scCO}_{2} / \mathrm{H}_{2} \mathrm{O}$ extract from $M$. sinensis harvested in June, Figure S11. QATR- FTIR spectrum of the $\mathrm{scCO}_{2}$ extract from M. sacchariflorus harvested in June, Figure S12. QATR-FTIR spectrum of the $\mathrm{scCO}_{2} / \mathrm{H}_{2} \mathrm{O}$ extract from $M$. sacchariflorus harvested in June, Figure S13. QATR-FTIR spectrum of the $\mathrm{scCO}_{2}$ extract from $S$. pectinata harvested in June, Figure S14. QATR-FTIR spectrum of the $\mathrm{scCO}_{2} / \mathrm{H}_{2} \mathrm{O}$ extract from $S$. pectinata harvested in June. 
Author Contributions: Conceptualization, M.A.; methodology, M.O., B.B. and M.A.; formal analysis, B.B. and M.A.; investigation, M.O.; resources, M.O., B.B. and M.A.; data curation, M.A.; writing—original draft preparation, M.O. and M.A.; writing-review and editing, B.B., M.J.S. and M.A.; visualization, M.O., B.B. and M.A.; supervision. M.A.; project administration, B.B. and M.A.; funding acquisition. M.A. and M.J.S. All authors have read and agreed to the published version of the manuscript.

Funding: This research was funded by the National (Polish) Centre for Research and Development (NCBiR), titled "Environment, agriculture and forestry", project: BIOproducts from lignocellulosic biomass derived from MArginal land to fill the Gap In the Current national bioeconomy, No. BIOSTRATEG3/344253/2/NCBR/2017.

Institutional Review Board Statement: Not applicable.

Informed Consent Statement: Not applicable.

Acknowledgments: We would like to thank the University of Warmia and Mazury in Olsztyn, Faculty of Agriculture and Forestry, Department of Genetics, Plant Breeding and Bioresource Engineering (grant No. 30.610.007-110), for the materials and the Supercritical Extraction Department, ŁUKASZEWICZ Research Network-New Chemical Syntheses Institute (Puławy, Poland), for the extracts.

Conflicts of Interest: The authors declare no conflict of interest.

\section{References}

1. Keoleian, G.A.; Volk, T.A. Renewable energy from willow biomass crops: Life cycle energy, environmental and economic performance. Crit. Rev. Plant Sci. 2005, 24, 385-406. [CrossRef]

2. Stolarski, M.J.; Warmiński, K.; Krzyżaniak, M. Energy value of yield and biomass quality of poplar grown in two consecutive 4-year harvest rotations in the north-east of Poland. Energies 2020, 13, 1495. [CrossRef]

3. Stolarski, M.J.; Niksa, D.; Krzyżaniak, M.; Tworkowski, J.; Szczukowski, S. Willow productivity from small- and large-scale experimental plantations in Poland from 2000 to 2017. Renew. Sustain. Energy Rev. 2019, 101, 461-475. [CrossRef]

4. James, L.K.; Swinton, S.M.; Thelen, K.D. Profitability analysis of cellulosic energy crops compared with corn. Agron. J. 2010, 102, 675-687. [CrossRef]

5. Scalbert, A.; Manach, C.; Morand, C.; Rémésy, C.; Jiménez, L. Dietary polyphenols and the prevention of diseases. Crit. Rev. Food Sci. Nutr. 2005, 45, 287-306. [CrossRef]

6. Madunić, J.; Madunić, I.V.; Gajski, G.; Popić, J.; Garaj-Vrhovac, V. Apigenin: A dietary flavonoid with diverse anticancer properties. Cancer Lett. 2018, 413, 11-22. [CrossRef]

7. Anhê, F.F.; Desjardins, Y.; Pilon, G.; Dudonné, S.; Genovese, M.I.; Lajolo, F.M.; Marette, A. Polyphenols and type 2 diabetes: A prospective review. PharmaNutrition 2013, 1, 105-114. [CrossRef]

8. Marranzano, M.; Rosa, R.L.; Malaguarnera, M.; Palmeri, R.; Tessitori, M.; Barbera, A.C. Polyphenols: Plant sources and food industry applications. Curr. Pharm. Des. 2018, 24, 4125-4130. [CrossRef]

9. Mittal, A.K.; Chisti, Y.; Banerjee, U.C. Synthesis of metallic nanoparticles using plant extracts. Biotechnol. Adv. 2013, 31, 346-356. [CrossRef] [PubMed]

10. Milinčić, D.D.; Popović, D.A.; Lević, S.M.; Kostić, A.Ž.; Tešić, Ž.L.; Nedović, V.A.; Pešić, M.B. Application of polyphenol-loaded nanoparticles in food industry. Nanomaterials 2019, 9, 1629. [CrossRef]

11. Krishnaiah, D.; Sarbatly, R.; Nithyanandam, R. A review of the antioxidant potential of medicinal plant species. Food Bioprod. Process. 2011, 89, 217-233. [CrossRef]

12. Gessner, D.K.; Ringseis, R.; Eder, K. Potential of plant polyphenols to combat oxidative stress and inflammatory processes in farm animals. J. Anim. Physiol. Anim. Nutr. 2017, 101, 605-628. [CrossRef]

13. González de Llano, D.; Liu, H.; Khoo, C.; Moreno-Arribas, M.V.; Bartolomé, B. Some new findings regarding the antiadhesive activity of cranberry phenolic compounds and their microbial-derived metabolites against uropathogenic bacteria. J. Agric. Food Chem. 2019, 67, 2166-2174. [CrossRef]

14. Zhu, J.; Huang, X.; Zhang, F.; Feng, L.; Li, J. Inhibition of quorum sensing, biofilm, and spoilage potential in Shewanella baltica by green tea polyphenols. J. Microbiol. 2015, 53, 829-836. [CrossRef]

15. Fleitas Martínez, O.; Cardoso, M.H.; Ribeiro, S.M.; Franco, O.L. Recent advances in anti-virulence therapeutic strategies with a focus on dismantling bacterial membrane microdomains, toxin neutralization, quorum-sensing interference and biofilm inhibition. Front. Cell. Infect. Microbiol. 2019, 9, 74. [CrossRef]

16. Kowalska, G.; Pankiewicz, U.; Kowalski, R. Evaluation of chemical composition of some Silphium, L. species as alternative raw materials. Agriculture 2020, 10, 132. [CrossRef]

17. Pan, L.; Sinden, M.R.; Kennedy, A.H.; Chai, H.; Watson, L.E.; Graham, T.L.; Kinghorn, A.D. Bioactive constituents of Helianthus tuberosus (Jerusalem artichoke). Phytochem. Lett. 2009, 2, 15-18. [CrossRef] 
18. Nizioł-Łukaszewska, Z.; Furman-Toczek, D.; Zagórska-Dziok, M. Antioxidant activity and cytotoxicity of Jerusalem artichoke tubers and leaves extract on HaCaT and BJ fibroblast cells. Lipids. Health Dis. 2018, 17, 280. [CrossRef] [PubMed]

19. Kowalski, R.; Kędzia, B. Antibacterial activity of Silphium perfoliatum extracts. Pharm. Biol. 2007, 45, 494-500. [CrossRef]

20. Kowalski, R. Silphium, L. extracts-composition and protective effect on fatty acids content in sunflower oil subjected to heating and storage. Food Chem. 2009, 112, 820-830. [CrossRef]

21. Ahmad, P.; Jaleel, C.A.; Salem, M.A.; Nabi, G.; Sharma, S. Roles of enzymatic and nonenzymatic antioxidants in plants during abiotic stress. Crit. Rev. Biotechnol. 2010, 30, 161-175. [CrossRef]

22. Stolarski, M.J.; Warmiński, K.; Krzyżaniak, M.; Tyśkiewicz, K.; Olba-Zięty, E.; Graban, Ł.; Lajszner, W.; Załuski, D.; Wiejak, R.; Kamiński, P.; et al. How does extraction of biologically active substances with supercritical carbon dioxide affect lignocellulosic biomass properties? Wood Sci. Technol. 2020, 54, 519-546. [CrossRef]

23. Malm, A.; Grzegorczyk, A.; Biernasiuk, A.; Baj, T.; Rój, E.; Tyśkiewicz, K.; Dębczak, A.; Stolarski, M.J.; Krzyżaniak, M.; Olba-Zięty, E. Could supercritical extracts from the aerial parts of Helianthus salicifolius A. Dietr. and Helianthus tuberosus L. be regarded as potential raw materials for biocidal purposes? Agriculture 2021, 11, 10. [CrossRef]

24. Ostolski, M.; Adamczak, M.; Brzozowski, B.; Wiczkowski, W. Antioxidant activity and chemical characteristics of supercritical $\mathrm{CO}_{2}$ and water extracts from willow and poplar. Molecules 2021, 26, 545. [CrossRef]

25. Singleton, V.L.; Rossi, J.A. Colorimetry of total phenolics with phosphomolybdic-phosphotungstic acid reagents. Am. J. Enol. Vitic. 1965, 16, 144-158.

26. Lamaison, J.L.; Carnat, A. The amount of main flavonoids in flowers and leaves of Crataegus monogyna Jacq. and Crataegus laevigata (Poiret) DC. (Rosaceae). Pharm. Acta Helv. 1990, 65, 315-320.

27. Blois, M.S. Antioxidant determinations by the use of a stable free radical. Nature 1958, 181, 1199-1200. [CrossRef]

28. Rasouli, H.; Farzaei, M.H.; Mansouri, K.; Mohammadzadeh, S.; Khodarahmi, R. Plant cell cancer: May natural phenolic compounds prevent onset and development of plant cell malignancy? A literature review. Molecules 2016, 21, 1104. [CrossRef]

29. Quideau, S.; Deffieux, D.; Douat-Casassus, C.; Pouységu, L. Plant polyphenols: Chemical properties, biological activities, and synthesis. Angew. Chem. Int. Ed. 2011, 50, 586-621. [CrossRef]

30. Aggarwal, S.; Johnson, S.; Hakovirta, M.; Sastri, B.; Banerjee, S. Removal of water and extractives from softwood with supercritical carbon dioxide. Ind. Eng. Chem. Res. 2019, 58, 3170-3174. [CrossRef]

31. Trubetskaya, A.; Budarin, V.; Arshadi, M.; Magalhães, D.; Kazanç, F.; Hunt, A.J. Supercritical extraction of biomass as an effective pretreatment step for the char yield control in pyrolysis. Renew. Energy 2021, 170, 107-117. [CrossRef]

32. Attard, T.M.; Bukhanko, N.; Eriksson, D.; Arshadi, M.; Geladi, P.; Bergsten, U.; Budarin, V.L.; Clark, J.H.; Hunt, A.J. Supercritical extraction of waxes and lipids from biomass: A valuable first step towards an integrated biorefinery. J. Clean. Prod. 2018, 177, 684-698. [CrossRef]

33. Showkat, M.M.; Falck-Ytter, A.B.; Strætkvern, K.O. Phenolic acids in Jerusalem artichoke (Helianthus tuberosus L.): Plant organ dependent antioxidant activity and optimized extraction from leaves. Molecules 2019, 24, 3296. [CrossRef] [PubMed]

34. Balcerek, M.; Rak, I.; Majtkowska, G.; Majtkowski, W. Antioxidant activity and total phenolic compounds in extracts of selected grasses (Poaceae). Herba Pol. 2009, 55, 215-220.

35. Parveen, I.; Wilson, T.; Donnison, I.S.; Cookson, A.R.; Hauck, B.; Threadgill, M.D. Potential sources of high value chemicals from leaves, stems and flowers of Miscanthus sinensis 'Goliath' and Miscanthus sacchariflorus. Phytochem 2013, 92, 160-167. [CrossRef] [PubMed]

36. Uwineza, P.A.; Waśkiewicz, A. Recent advances in supercritical fluid extraction of natural bioactive compounds from natural plant materials. Molecules 2020, 25, 3847. [CrossRef] [PubMed]

37. Tyśkiewicz, K.; Konkol, M.; Rój, E. The application of supercritical fluid extraction in phenolic compounds isolation from natural plant materials. Molecules 2018, 23, 2625. [CrossRef]

38. Da Porto, C.; Decorti, D.; Natolino, A. Water and ethanol as co-solvent in supercritical fluid extraction of proanthocyanidins from grape marc: A comparison and a proposal. J Supercrit. Fluids 2014, 87, 1-8. [CrossRef]

39. He, J.-Z.; Shao, P.; Liu, J.-H.; Ru, Q.-M. Supercritical carbon dioxide extraction of flavonoids from pomelo (Citrus grandis (L.) Osbeck) peel and their antioxidant activity. Int. J. Mol. Sci. 2012, 13, 13065-13078. [CrossRef]

40. Miguez, F.E.; Villamil, M.B.; Long, S.P.; Bollero, G.A. Meta-analysis of the effects of management factors on Miscanthus $\times$ giganteus growth and biomass production. Agric. For. Meteorol. 2008, 148, 280-1292. [CrossRef]

41. Lemos, M.F.; Lemos, M.F.; Pacheco, H.P.; Endringer, D.C.; Scherer, R. Seasonality modifies rosemary's composition and biological activity. Ind. Crops Prod. 2015, 70, 41-47. [CrossRef]

42. Cao, Y.; Fang, S.; Fu, X.; Shang, X.; Yang, W. Seasonal variation in phenolic compounds and antioxidant activity in leaves of Cyclocarya paliurus (Batal.) Iljinskaja. Forests 2019, 10, 624. [CrossRef]

43. Scognamiglio, M.; D’Abrosca, B.; Fiumano, V.; Golino, M.; Esposito, A.; Fiorentino, A. Seasonal phytochemical changes in Phillyrea angustifolia L.: Metabolomic analysis and phytotoxicity assessment. Phytochem. Lett. 2014, 8, 163-170. [CrossRef]

44. Pacifico, S.; Galasso, S.; Piccolella, S.; Kretschmer, N.; Pan, S.-P.; Marciano, S.; Bauer, R.; Monaco, P. Seasonal variation in phenolic composition and antioxidant and anti-inflammatory activities of Calamintha nepeta (L.) Savi. Food Res. Int. 2015, 69, 121-132. [CrossRef]

45. Bujor, O.C.; Le Bourvellec, C.; Volf, I.; Popa, V.I.; Dufour, C. Seasonal variations of the phenolic constituents in bilberry (Vaccinium myrtillus L.) leaves, stems and fruits, and their antioxidant activity. Food Chem. 2016, 213, 58-68. [CrossRef] 
46. Dela, G.; Or, E.; Ovadia, R.; Nissim-Levi, A.; Weiss, D.; Oren-Shamir, M. Changes in anthocyanin concentration and composition in 'Jaguar' rose flowers due to transient high-temperature conditions. Plant Sci. 2003, 164, 333-340. [CrossRef]

47. Fu, B.; Ji, X.; Zhao, M.; He, F.; Wang, X.; Wang, Y.; Liu, P.; Niu, L. The influence of light quality on the accumulation of flavonoids in tobacco (Nicotiana tabacum L.) leaves. J. Photochem. Photobiol. B. Biol. 2016, 162, 544-549. [CrossRef]

48. Rathee, J.S.; Hassarajani, S.A.; Chattopadhyay, S. Antioxidant activity of Nyctanthes arbor-tristis leaf extract. Food Chem. 2007, 103, 1350-1357. [CrossRef]

49. Zhang, L.; Gao, Y.; Zhang, Y.; Liu, J.; Yu, J. Changes in bioactive compounds and antioxidant activities in pomegranate leaves. Sci. Hortic. 2010, 123, 543-546. [CrossRef]

50. Vazquez-Olivo, G.; López-Martínez, L.X.; Contreras-Angulo, L.; Heredia, J.B. Antioxidant capacity of lignin and phenolic compounds from corn stover. Waste Biomass Valori. 2019, 10, 95-102. [CrossRef]

51. Vanderghem, C.; Jacquet, N.; Richel, A. Can lignin wastes originating from cellulosic ethanol biorefineries act as radical scavenging agents? Aust. J. Chem. 2014, 67, 1693-1699. [CrossRef]

52. Coates, J. Interpretation of infrared spectra. In A Practical Approach; Meyers, R.A., Ed.; Encyclopedia of Analytical Chemistry; John Wiley \& Sons, Ltd.: Chichester, UK, 2006; pp. 1-23. [CrossRef]

53. Hayat, J.; Akodad, M.; Moumen, A.; Baghour, M.; Skalli, A.; Ezrari, S.; Belmalha, S. Phytochemical screening, polyphenols, flavonoids and tannin content, antioxidant activities and FTIR characterization of Marrubium vulgare L. from 2 different localities of Northeast of Morocco. Heliyon 2020, 6, e05609. [CrossRef] [PubMed]

54. Huck, C.W. Advances of infrared spectroscopy in natural product research. Phytochem. Lett. 2015, 11, 384-393. [CrossRef]

55. Nogales-Bueno, J.; Baca-Bocanegra, B.; Rooney, A.; Hernández-Hierro, J.M.; Byrne, H.J.; Heredia, F.J. Study of phenolic extractability in grape seeds by means of ATR-FTIR and Raman spectroscopy. Food Chem. 2017, 232, 602-609. [CrossRef] [PubMed]

56. Rodrigues, V.H.; de Melo, M.M.R.; Portugal, I.; Silva, C.M. Extraction of Eucalyptus leaves using solvents of distinct polarity. Cluster analysis and extracts characterization. J. Supercrit. Fluids 2018, 135, 263-274. [CrossRef]

57. Thummajitsakul, S.; Samaikam, S.; Tacha, S.; Silprasit, K. Study on FTIR spectroscopy, total phenolic content, antioxidant activity and anti-amylase activity of extracts and different tea forms of Garcinia schomburgkiana leaves. LWT 2020, 134, 110005. [CrossRef] 